\title{
Bioassay to Study the Attachment of Xanthomonas albilineans on Sugarcane Leaves
}

Imène Mensi ${ }^{1}$, Jean-Heinrich Daugrois ${ }^{2}$ and Philippe Rott ${ }^{3}$ *

\author{
${ }^{1}$ Department of Biological Sciences and Plant Protection, Higher Agronomic Institute of Chott-Mariem, \\ Sousse, Tunisia; ${ }^{2}$ UMR BGPI, CIRAD, Montpellier, France; ${ }^{3}$ Department of Plant Pathology, University \\ of Florida, Everglades Research and Education Center, Belle Glade, USA \\ *For correspondence: pcrott@ufl.edu
}

\begin{abstract}
[Abstract] Sugarcane (interspecific hybrids of Saccharum species) is an economically important crop that provides $70 \%$ of raw table sugar production worldwide and contributes, in some countries, to bioethanol and electricity production. Leaf scald, caused by the bacterial plant pathogen Xanthomonas albilineans, is one of the major diseases of sugarcane. Dissemination of $X$. albilineans is mainly ensured by contaminated harvesting tools and infected stalk cuttings. However, some strains of this pathogen are transmitted by aerial means and are able to survive as epiphytes on the sugarcane phyllosphere before entering the leaves and causing disease. Here we present a protocol to estimate the capacity of attachment of $X$. albilineans to sugarcane leaves. Tissue-cultured sugarcane plantlets were immersed in a bacterial suspension of $X$. albilineans and leaf attachment of $X$. albilineans was determined by two methods: leaf imprinting (semi-quantitative method) and leaf washing/homogenization (quantitative method). These methods are important tools for evaluating pathogenicity of strains/mutants of the sugarcane leaf scald pathogen.
\end{abstract}

Keywords: Attachment, Leaf imprinting, Leaf scald, Pathogenicity, Phyllosphere, Sugarcane, Tissue culture, Xanthomonas albilineans

[Background] The mechanisms that govern the interactions between $X$. albilineans and its host plant (the sugarcane) are not well known. Albicidin, a phytotoxin produced by $X$. albilineans, is the only molecular factor which has been demonstrated to play a role in pathogenicity of this pathogen (Birch, 2001). However, pathogenicity of $X$. albilineans doesn't completely depend on albicidin. Albicidindeficient mutants are still able to colonize efficiently the sugarcane stalk and to produce disease symptoms (Birch, 2001; Rott et al., 2011). Studies using full grown sugarcane are space and time consuming. Bioassays using miniaturized plants (tissue-cultured plants) or detached leaf bioassays can be very useful because they are less space consuming and they allow the study of plant-pathogen interactions in controlled environments. In vitro propagation of plants is widely used to rapidly propagate disease-free planting material under controlled conditions (Kumar and Reddy, 2011). Additionally, leaf imprinting has been widely used to study the ecology of bacteria associated with the phyllosphere (Hirano and Upper, 2000; Yadav et al., 2010). However, to our knowledge, these techniques have never been associated to decipher pathogenicity of bacterial plant pathogens. To identify additional pathogenicity factors of $X$. albilineans, especially factors involved in the early phases of infection (epiphytic phase), we developed a new miniaturized bioassay using tissue cultured sugarcane plantlets. 
Attachment of $X$. albilineans to sugarcane leaves under axenic condition was reproduced (Fleites et al., 2013; Mensi et al., 2016). This bioassay will permit the rapid testing of leaf attachment capacity of wild type and mutant strains of the pathogen causing leaf scald disease, but also of other bacteria colonizing the sugarcane leaf canopy.

\section{Materials and Reagents}

1. Sterile scalpels blades (Swan Morton, catalog numbers: $n^{\circ} 11$ and $n^{\circ} 24$ )

2. Sterilized pipette tips $200 \mu \mathrm{l}$ (Thermo Fischer Scientific, Fischer Scientific, catalog number: 02-681-2) 1,000 $\mu \mathrm{l}$ (Thermo Fischer Scientific, Fischer Scientific, catalog number: 02-681-4)

3. Sterile plastic loops (Greiner Bio One, catalog number: 731171)

4. Falcon $15 \mathrm{ml}$ conical centrifuge tubes (SARSTEDT, catalog number: 62.554.502)

5. Soft tissue (Orapi Hygiène, catalog number: 186)

6. Disposable, sterile splinter removers/tweezers $-11.1 \mathrm{~cm}$. (4 1/4 in.) (TSIC Solution, catalog number: UTIL-1037)

7. $90 \times 15 \mathrm{~mm}$ Petri dishes (Corning, Gosselin ${ }^{\mathrm{TM}}$, catalog number: BP93B-15)

8. $1.5 \mathrm{ml}$ microcentrifuge tube (SARSTEDT, catalog number: 72.690 .001 )

9. Disposable pellet pestle for $1.5 \mathrm{ml}$ centrifuge tube (Kimble Chase Life Science and Research Products, catalog number: 749521-1500)

10. Sugarcane plantlets (cultivar CP68-1026 susceptible to leaf scald disease of sugarcane)

11. Xanthomonas albilineans wild type strains and mutants affected in pathogenicity (grown for 4 to 5 days on Wilbrink medium + appropriate antibiotics); for characteristics of mutants, see Fleites et al. (2013) and Mensi et al. (2016)

12. Sterile distilled water

13. Tween 20 (Sigma-Aldrich, catalog number: P2287)

14. Sucrose (Merck Millipore, catalog number: 107687)

15. Peptone (BD, Bacto ${ }^{\mathrm{TM}}$, catalog number: 211677 )

16. Potassium phosphate, dibasic, trihydrate, $\mathrm{K}_{2} \mathrm{HPO}_{4} \cdot 3 \mathrm{H}_{2} \mathrm{O}\left(\mathrm{EMD}\right.$ Millipore, Calbiochem ${ }^{\circledR}$, catalog number: 529567)

17. Magnesium sulfate heptahydrate $\left(\mathrm{MgSO}_{4} \cdot 7 \mathrm{H}_{2} \mathrm{O}\right)$ (EMD Millipore, catalog number: 105886$)$

18. Sodium sulfite $\left(\mathrm{Na}_{2} \mathrm{SO}_{3}\right)$ (EMD Millipore, catalog number: 106657)

19. Agar (BD, Bacto ${ }^{\mathrm{TM}}$, catalog number: 214010$)$

20. Potassium bromide, $\mathrm{KBr}$ (Sigma-Aldrich, catalog number: P0838)

21. Benomyl (Sigma-Aldrich, catalog number: 381586 )

22. Cycloheximide (Sigma-Aldrich, catalog number: C1988)

23. Ethanol (Sigma-Aldrich, catalog number: 32294) Note: This product has been discontinued.

24. Cephalexin (Sigma-Aldrich, catalog number: C0675000) 
25. Novobiocin (Sigma-Aldrich, catalog number: 1475008)

26. Kasugamycin (Sigma-Aldrich, catalog number: 19408-46-9)

27. Ammonium nitrate $\left(\mathrm{NH}_{4} \mathrm{NO}_{3}\right)$ (Sigma-Aldrich, catalog number: A3795)

28. Potassium nitrate $\left(\mathrm{KNO}_{3}\right)$ (Sigma-Aldrich, catalog number: P8291)

29. Calcium nitrate tetrahydrate $\left(\mathrm{Ca}\left(\mathrm{NO}_{3}\right)_{2} \cdot 4 \mathrm{H}_{2} \mathrm{O}\right)$ (Sigma-Aldrich, catalog number: $\mathrm{C} 2786$ )

30. Magnesium sulfate heptahydrate $\left(\mathrm{MgSO}_{4} \cdot 7 \mathrm{H}_{2} \mathrm{O}\right)$ (Sigma-Aldrich, catalog number: 63138)

31. Potassium phosphate monobasic $\left(\mathrm{KH}_{2} \mathrm{PO}_{4}\right)$ (Sigma-Aldrich, catalog number: $\left.\mathrm{P} 5655\right)$

32. Potassium chloride (KCl) (Sigma-Aldrich, catalog number: P5405)

33. Boric acid $\left(\mathrm{H}_{3} \mathrm{BO}_{3}\right)$ (Sigma-Aldrich, catalog number: B6768)

34. Manganese(II) sulfate monohydrate $\left(\mathrm{MnSO}_{4} \cdot \mathrm{H}_{2} \mathrm{O}\right)$ (Sigma-Aldrich, catalog number: M7899)

35. Zinc sulfate heptahydrate $\left(\mathrm{ZnSO}_{4} \cdot 7 \mathrm{H}_{2} \mathrm{O}\right)$ (Sigma-Aldrich, catalog number: $\left.\mathrm{Z1001}\right)$

36. Potassium iodide (KI) (Sigma-Aldrich, catalog number: P8166)

37. Ammonium molybdate tetrahyddrate $\left(\left(\mathrm{NH}_{4}\right)_{6} \mathrm{Mo}_{7} \mathrm{O}_{24} \cdot 4 \mathrm{H}_{2} \mathrm{O}\right)$ (Sigma-Aldrich, catalog number: M1019)

38. Copper(II) nitrate trihydrate $\left(\mathrm{Cu}\left(\mathrm{NO}_{3}\right)_{2} \cdot 3 \mathrm{H}_{2} \mathrm{O}\right)$ (Sigma-Aldrich, catalog number: 61194)

39. Iron(II) sulfate heptahydrate $\left(\mathrm{FeSO}_{4} \cdot 7 \mathrm{H}_{2} \mathrm{O}\right)$ (EMD Millipore, catalog number: 103965)

40. $\mathrm{Na}_{2} \mathrm{EDTA} \cdot 2 \mathrm{H}_{2} \mathrm{O}$ (Sigma-Aldrich, catalog number: E5134)

41. Nicotinic acid (Sigma-Aldrich, catalog number: N4126)

42. Pyridoxol hydrochlorid (Sigma-Aldrich, catalog number: P6280)

43. Myo-inositol (Sigma-Aldrich, catalog number: 17508)

44. Thiamine dichloride (Sigma-Aldrich, catalog number: T1270)

45. Phytagel (Sigma-Aldrich, catalog number: P8169)

46. Wilbrink medium (WM) (see Recipes)

47. Wilbrink Selective Davis (WSD) medium (see Recipes)

48. Macronutrients (see Recipes)

49. Micronutrients (see Recipes)

50. Ferric EDTA (see Recipes)

51. Fuji vitamins (see Recipes)

52. Nutritive medium for growth of sugarcane plantlets (see Recipes)

\section{Equipment}

1. Growth chamber

2. $200 \times 20 \mathrm{~mm}$ Pyrex test tubes with cap (Legallais, catalog number: 761224)

3. $200 \mathrm{~mm}$ long tweezers with blunt tips (VWR, catalog number: 82027-436)

4. Micropipettes

20-200 $\mu \mathrm{l}$ (Eppendorf, catalog number: 3120000054)

100-1,000 $\mu$ l (Eppendorf, catalog number: 3120000062)

5. Scalpels (Swan Morton, catalog numbers: $N^{\circ} 3 G$ S/S and $N^{\circ} 4 G S / S$ ) 
6. Incubator for microbiology (Memmert, model: B40)

Note: This product has been discontinued.

7. Benchtop vortex (Scientific Industries, model: Vortex Genie 2)

8. Spectrophotometer (Eppendorf Biophotometer)

9. 250 or $500 \mathrm{ml}$ wide neck Erlenmeyer flasks (Borosilicate glass) (Duran, catalog number: 21226 36 or 2122644 )

10. Laminar flow cabinet or sterile hood

11. Autoclave

\section{Software}

1. Package R, version 2.14.1 (R Development Core Team)

\section{Procedure}

A. Preparation of tissue-cultured sugarcane plantlets

1. Tissue cultured plantlets of sugarcane cultivar CP68-1026 originating from apex tissue are propagated and maintained in a growth chamber at $28^{\circ} \mathrm{C}$ with $12 \mathrm{~h}$ light.

2. Four weeks prior to inoculation, young secondary tillers are transferred into new $200 \times 20 \mathrm{~mm}$ test tubes containing the nutritive medium for tissue cultured plantlets, as follows:

a. Using $200 \mathrm{~mm}$ long tweezers, remove the tissue cultured-plantlet from the tube and place it on a glass plate under a sterile hood, separate young secondary tillers from the primary tiller with a scalpel and sterile blades.

b. Using $200 \mathrm{~mm}$ long tweezers, place each secondary tiller in a new $200 \times 20 \mathrm{~mm}$ test tube containing the nutritive medium for sugarcane plantlets. Secondary tillers may vary in size but only tillers that were $\mathbf{1 5 0 - 2 0 0 ~ m m ~ l o n g ~ w e r e ~ t r a n s f e r r e d ~ f o r ~ f u t u r e ~ i n o c u l a t i o n . ~ A l l ~}$ transferred plantlets must have two to four unfolded leaves.

3. Incubate the test tubes in a growth chamber at $28{ }^{\circ} \mathrm{C}$ with $12 \mathrm{~h}$ of light for four weeks.

B. Bacterial inoculum preparation

1. Five days before plant inoculation, streak out each strain of $X$. albilineans to be tested from $-80{ }^{\circ} \mathrm{C}$ distilled water stocks using a sterilized blade or a pipet tip onto WM agar plates with appropriate antibiotics (for mutant strains) and let the cultures grow for 5 days in an incubator at $28^{\circ} \mathrm{C}$.

2. For each strain, suspend bacterial colonies from the agar plate with a sterile polypropylene loop in $10 \mathrm{ml}$ of sterile distilled water in a $15 \mathrm{ml}$ Falcon conical centrifuge tubes (to obtain a turbid suspension). Vortex the bacterial suspension manually or gently with a benchtop vortex and then measure its optical density at $600 \mathrm{~nm}\left(\mathrm{OD}_{600}\right)$ using a spectrophotometer. 
3. To prepare the stock suspension, adjust the bacterial suspension with sterile distilled water to obtain an $\mathrm{OD}_{600}=0.25-0.30$ which corresponds to $10^{9}$ Colony Forming Units (CFU)/ml.

4. To prepare the inoculum at $10^{7} \mathrm{CFU} / \mathrm{ml}$, dilute $5 \mathrm{ml}$ of the bacterial suspension calibrated at $10^{9}$ $\mathrm{CFU} / \mathrm{ml}$ in $495 \mathrm{ml}$ of sterile distilled water in a $500 \mathrm{ml}$ Erlenmeyer flask.

C. Sugarcane plantlets inoculation by immersion

1. For inoculation, use plantlets with two to four fully unfolded leaves (Figure 1).

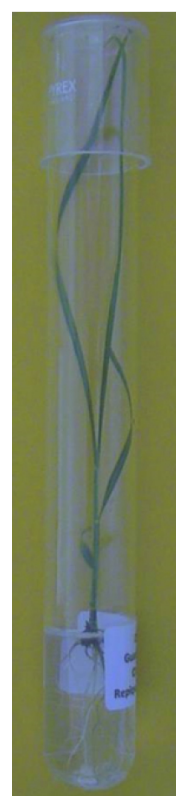

Figure 1. Sugarcane plantlet exhibiting three fully expanded leaves in a test tube

2. Use sterile tweezers to immerse the leaves of the tissue-cultured plantlets into the bacterial suspension adjusted at $10^{7} \mathrm{CFU} / \mathrm{ml}$ for $30-40 \mathrm{sec}$ (Figure 2). During immersion of leaves, make gentle circular movements of the Erlenmeyer flask in order to optimize the contact of the bacterial suspension with the sugarcane leaf surfaces. 


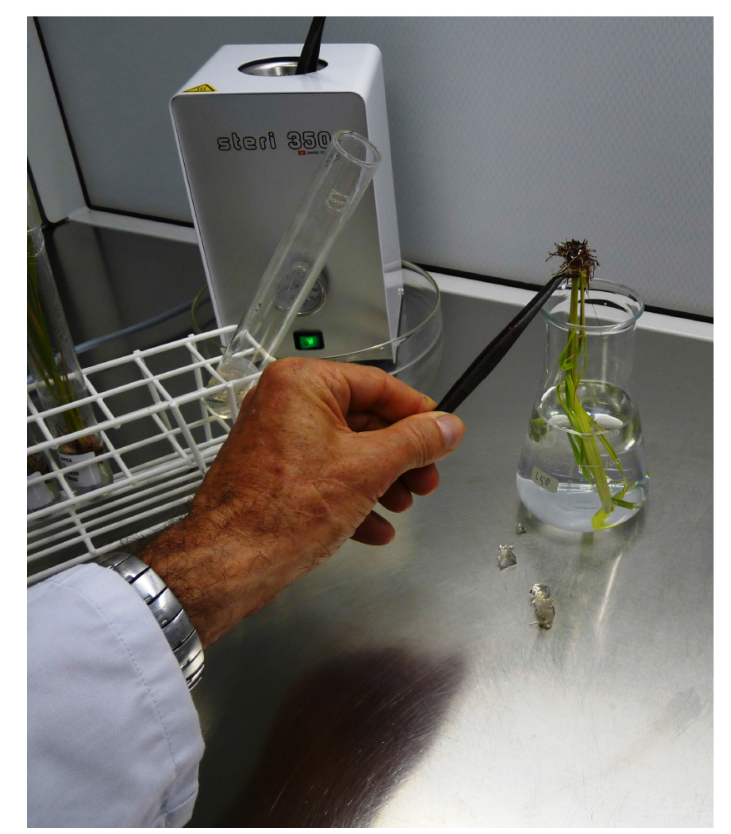

Figure 2. Immersion of leaves of a sugarcane plantlet for 30-40 sec in a $X$. albilineans suspension adjusted at $10^{7} \mathrm{CFU} / \mathrm{ml}$

3. After immersion, remove excess of bacterial suspension by dragging the leaves across the edge of the wall of the Erlenmeyer flask: no visible droplet should be seen on the leaf surfaces. Then, replace the inoculated plantlets in the same test tubes containing the same nutritive medium (using sterile tweezers).

4. Keep inoculated plantlets in a growth chamber at $28^{\circ} \mathrm{C}$ with $12 \mathrm{~h}$ of light for 14 days.

5. Inoculate at least six (for leaf imprinting assay, cf. D.1) to 15 (for leaf washing and tissue homogenization assay, cf. D.2) sugarcane plantlets per strain of $X$. albilineans and distribute them randomly in the growth chamber.

6. Inoculate control plantlets with only sterile distilled water.

D. Determination of $X$. albilineans leaf attachment Leaf attachment of $X$. albilineans can be determined using two methods: 1. imprints of sugarcane leaves on selective medium (semi-quantitative method) and 2. leaf washing and tissue homogenization (quantitative method).

1. Determination of capacity of $X$. albilineans leaf attachment by leaf imprinting

a. Fourteen days after immersion, remove the inoculated sugarcane plantlets (one by one) from the test tubes and put them on a sterile soft tissue (Figure 3). Use a scalpel with a sterile blade to remove leaves (remove and imprint only non-withered leaves). 

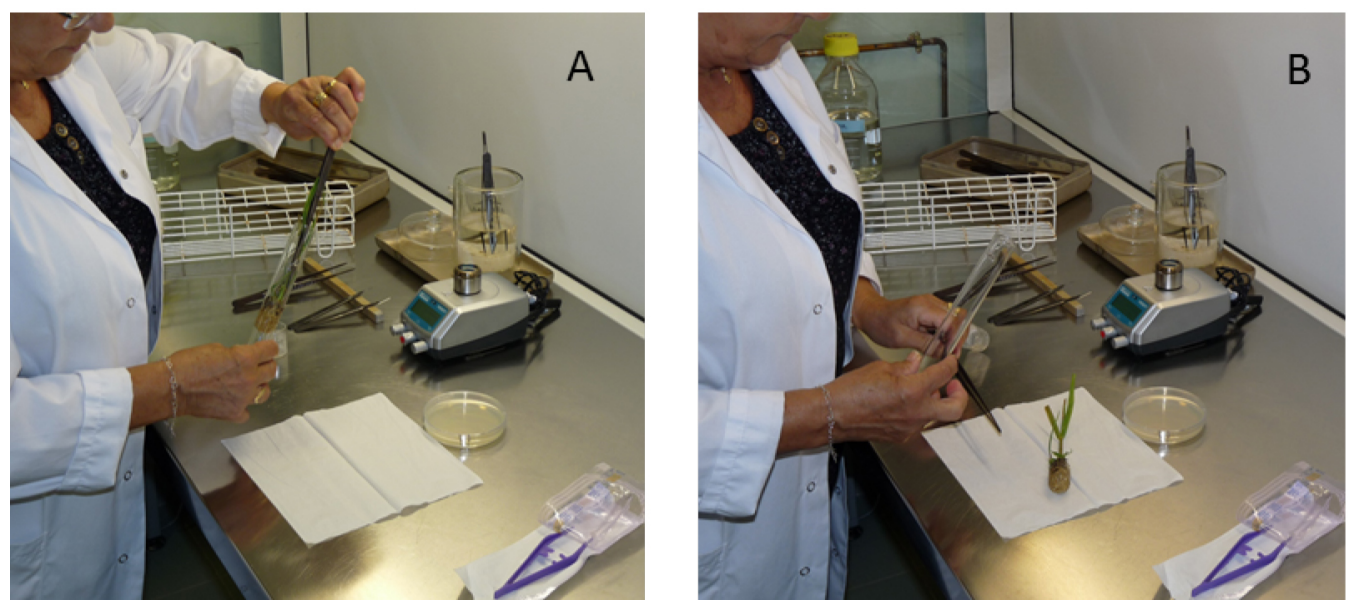

Figure 3. Removal of the sugarcane plantlet from the test tube in an aseptic work area (laminar flow cabinet). A. Remove the inoculated sugarcane plantlet from the test tube using long sterile tweezers, 14 days after immersion and B. put it on a sterile soft tissue.

b. Using disposable sterile tweezers, gently place detached leaves on WSD medium in $90 \mathrm{x}$ $15 \mathrm{~mm}$ plates and apply a soft pressure with the tweezers to imprint the lower and then the upper leaf surface on the agar medium (Figure 4). Leaves for imprinting may vary in length but must have a green color. If the length of the leaf exceeds the plate diameter, cut the leaf into two or three fragments before performing the imprint. The quality of the imprinted leaf area can be observed by trans-illumination using day or artificial light.

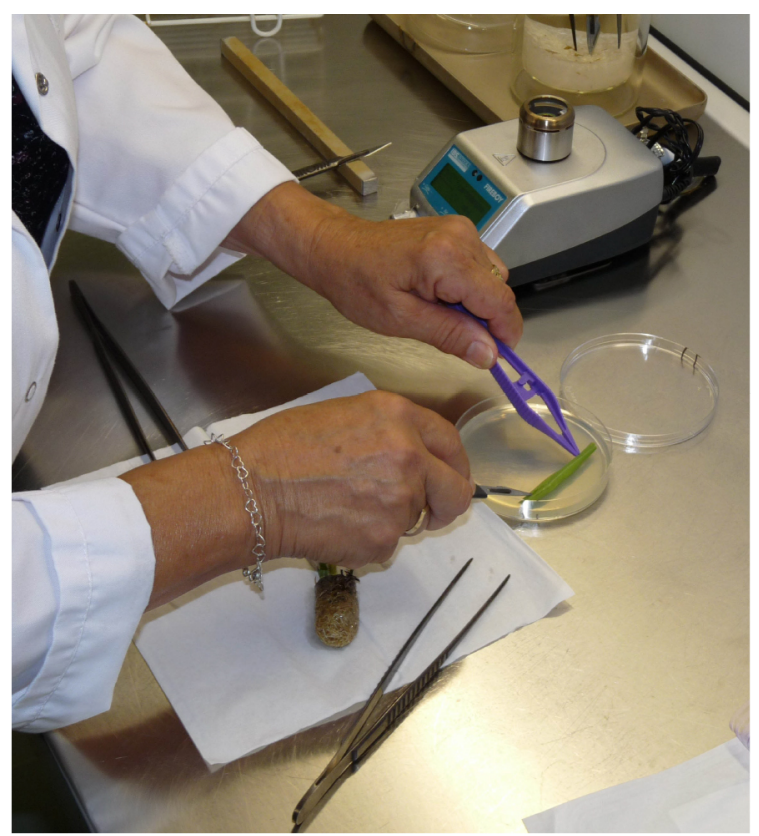

Figure 4. Imprint the inoculated sugarcane leaf (upper and lower surfaces) on WSD medium using disposable sterile tweezers

c. Place agar plates in an incubator at $28^{\circ} \mathrm{C}$ for 5 days. 
d. Five days after incubation, examine plates for presence or absence of $X$. albilineans colonies in the imprint area. Density of $X$. albilineans colonies growing in the imprint area can vary between absences of colonies to confluent growth of bacteria in the imprint area (Figure 5).

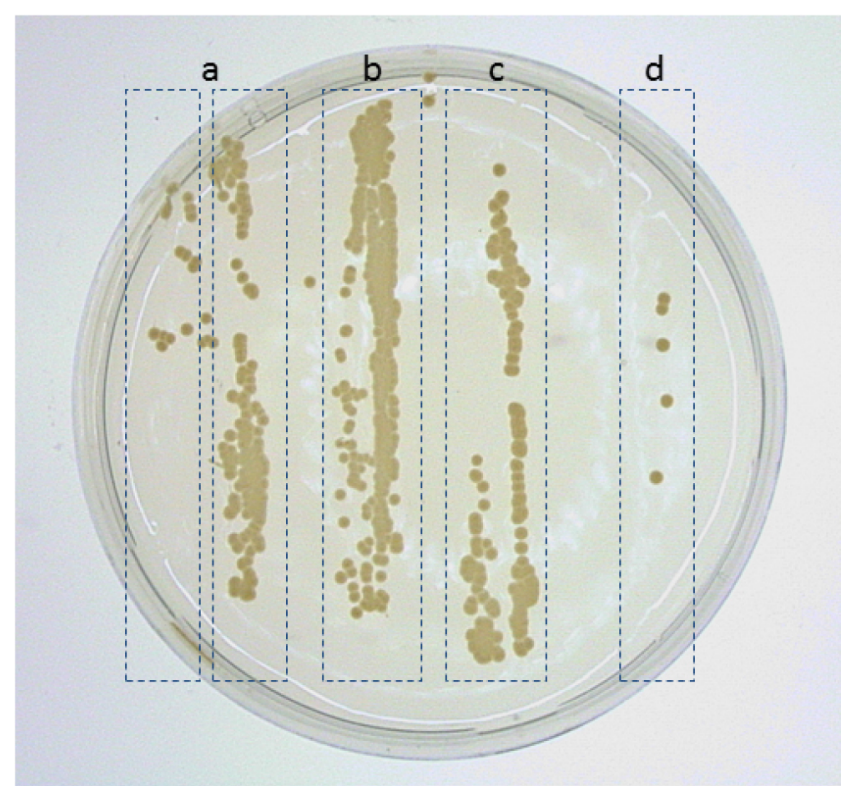

Figure 5. Growth of colonies of $X$. albilineans in imprints of sugarcane leaves on WSD medium, 14 days after immersion of leaves in a bacterial suspension adjusted at $10^{7}$ $\mathrm{CFU} / \mathrm{ml}$. a. Imprint of the upper surface of leaf $n 1 ; b$. Imprint of the lower surface of leaf $n 1 ; \mathrm{c}$. Imprint of the upper surface of leaf $n 2$; d. Imprint of the lower surface of leaf n2. Leaf $n 1$ is the first leaf from the top of the sugarcane plantlet that is completely unfolded. Leaf $\mathrm{n} 2$ is the leaf immediately below leaf $\mathrm{n} 1$ (Reprinted from Fleites et al., 2013).

e. To estimate Extent of Leaf Attachment (ELA) of $X$. albilineans, give a score ranging from 0 to 6 to each leaf imprint (lower and upper surfaces) using the following scale (Figure 6):

$0=0$ to 5 five colonies in the leaf imprint,

$1=6$ to 50 colonies in the leaf imprint,

$2=$ more than 50 colonies and no confluent growth,

$3=$ confluent growth of bacteria in less than $10 \%$ of the leaf imprint,

$4=$ confluent growth of bacteria in $10 \%$ to $40 \%$ of the leaf imprint,

$5=$ confluent growth of bacteria in $41 \%$ to $80 \%$ of the leaf imprint,

$6=$ confluent growth of bacteria in $81 \%$ to $100 \%$ of the imprint. 

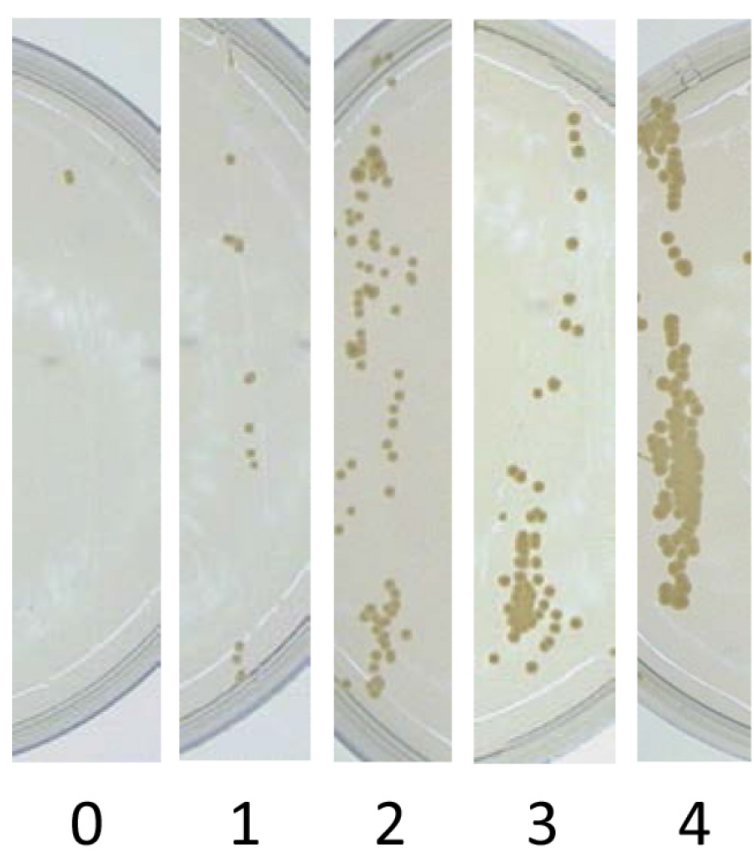

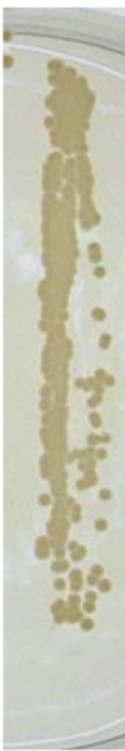

4
5

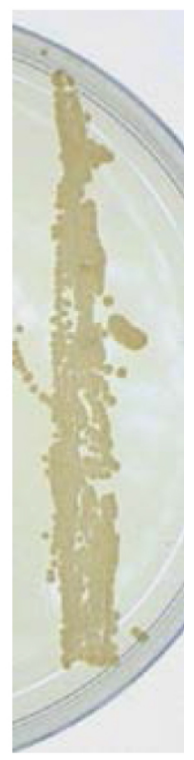

6

Figure 6. Score used to estimate Extent of Leaf Attachment (ELA). $0=0$ to 5 five colonies in the leaf imprint, $1=6$ to 50 colonies in the leaf imprint, $2=$ more than 50 colonies and no confluent growth, 3 = confluent growth of bacteria in less than $10 \%$ of the leaf imprint, $4=$ confluent growth of bacteria in $10 \%$ to $40 \%$ of the leaf imprint, $5=$ confluent growth of bacteria in $41 \%$ to $80 \%$ of the leaf imprint, $6=$ confluent growth of bacteria in $81 \%$ to $100 \%$ of the leaf imprint (Reprinted from Mensi et al., 2016).

f. Calculate ELA for each inoculated plantlet as follows:

$E L A=100\left(\left[1 \times N_{1}+2 \times N_{2}+3 \times N_{3}+4 \times N_{4}+5 \times N_{5}+6 \times N_{6}\right] /\left[6 \times N_{T}\right]\right)$

Where,

$N_{i}$ is the number of leaf imprints with score $i$ ( $i$ is the individual scale),

$N_{T}$ is the total number of leaf imprints per plantlet.

g. Calculate average ELA for each bacterial strain or mutant tested using all ELA values obtained for the six inoculated plantlets.

2. Determination of $X$. albilineans leaf attachment by leaf washing and tissue homogenization.

For this bioassay, 15 sugarcane plantlets were inoculated per strain. At each sampling time (1 h, 7 and 14 days), five plantlets and two leaves per plantlet were individually used to determine attachment capacity of $X$. albilineans. The experiment is repeated independently at least two times. Leaf washing is performed to detach and quantify bacteria that are located on the leaf surface, whereas leaf homogenization is performed to isolate and quantify bacteria from protected areas (such as stomatal chambers) or from inside the leaf.

a. Leaf washing

i. At $1 \mathrm{~h}, 7$ and 14 days after immersion of sugarcane leaves in the bacterial suspension, use sterile tweezers to remove plantlets from the test tubes, put them on sterile soft 
tissue (Figure 3) and cut two leaves from each plantlet (using a scalpel with a sterile blade). Collect only inoculated and non-withered leaves.

ii. $\quad$ Cut a $7 \mathrm{~cm}$ long fragment from each leaf (Figure 7A) and immerse each fragment individually in a $1.5 \mathrm{ml}$ micro-centrifuge tube containing $1 \mathrm{ml}$ of sterile distilled water with $0.005 \%$ Tween 20 (Figure 7B). Note that each leaf fragment is analyzed separately.
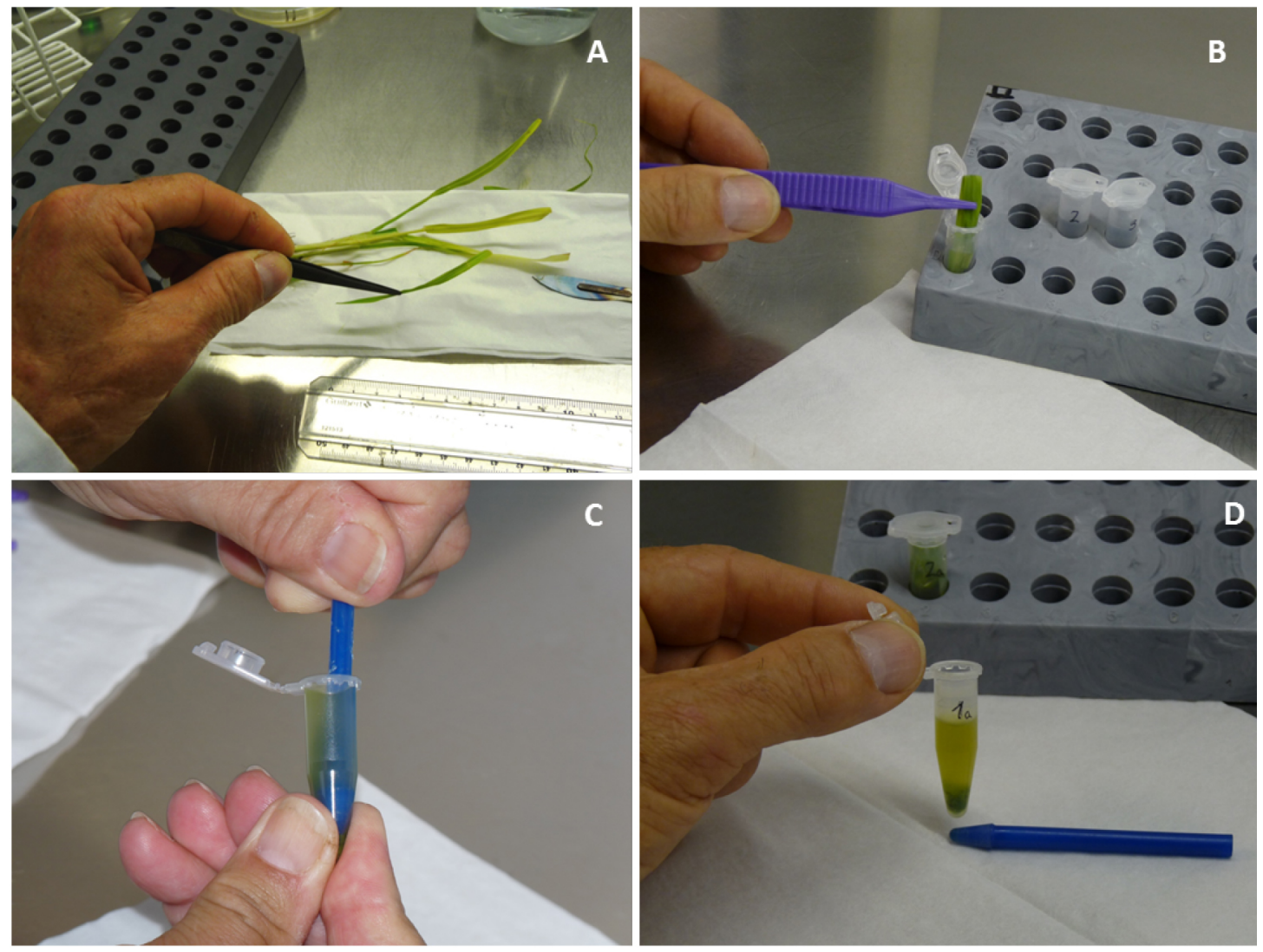

Figure 7. Steps describing leaf washing and tissue homogenization. A. Cut a $7 \mathrm{~cm}$ long fragment from two leaves of each inoculated plantlet. B. For leaf washing, immerse each leaf fragment individually in a $1.5 \mathrm{ml}$ micro-centrifuge tube containing $1 \mathrm{ml}$ of sterile distilled water and $0.005 \%$ Tween 20. C. For tissue homogenization, use a pestle made for micro-centrifuge tubes and homogenize the leaf fragment in the same tube, each tube containing $820 \mu$ l of wash water after removal of $180 \mu$ for bacterial counts. D. Homogenized leaf tissue.

iii. Vortex the tubes vigorously for $10 \mathrm{sec}$ to wash leaf fragments.

iv. Use $100 \mu \mathrm{l}$ of each wash water to make 10 and 100 fold dilutions.

v. Gently drop three or four times $20 \mu \mathrm{l}$ of each undiluted, 10 and 100-fold diluted wash water on WSD plates.

vi. Place the agar plates in an incubator at $28^{\circ} \mathrm{C}$ for 6 days (Figure 8). 


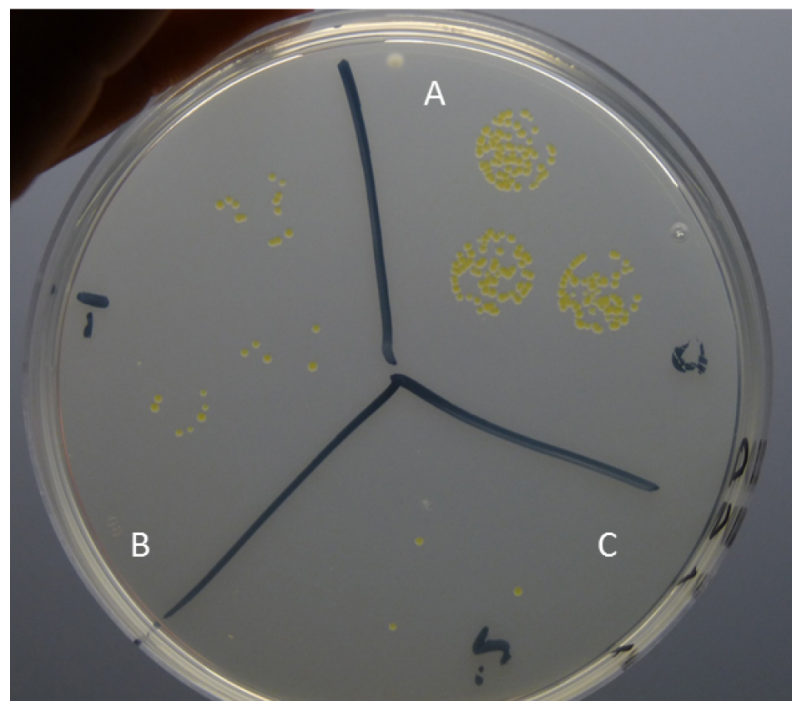

Figure 8. Growth of $X$. albilineans colonies in drops of undiluted (A), 10 (B) and 100 times (C) diluted wash water or homogenized tissue, 6 days after deposition on WSD plates

b. Leaf homogenization after leaf washing

i. Using a pestle made for $1.5 \mathrm{ml}$ micro-centrifuge tubes, homogenize each leaf fragment in the remaining wash water $(820 \mu \mathrm{l}$ after removal of $180 \mu \mathrm{l}$ in A. for determination of bacterial populations) for 5 min (Figures 7C and 7D).

ii. Use $100 \mu \mathrm{l}$ of each homogenized tissue suspension to make 10 and 100 fold dilutions.

iii. Gently drop three or four times $20-\mu \mathrm{l}$ of undiluted, 10 and 100 times diluted homogenized tissue on WSD plates. Place the agar plates in the incubator at $28{ }^{\circ} \mathrm{C}$ for 6 days.

c. Determination of bacterial population densities

i. Count colonies for each dilution and each of the three-four replications after 6 days of growth; calculate the average number of colonies and correct for dilutions. For example, 15 colonies on the $10^{-1}$ dilution plate correspond to 7,500 CFU present in the leaf section. Convert to $\log _{10} \mathrm{CFU}$ per leaf section for the wash water or homogenized tissue.

ii. For wash water and for homogenized tissue, calculate average $\log _{10}$ CFU for each bacterial strain or mutant tested using all values obtained for the six inoculated plantlets.

\section{Data analysis}

1. Data were analyzed using the statistical software package $R$, version 2.14.1 (R Development Core Team) as described by Mensi et al. (2016). Extent of Leaf Attachment (ELA) values are the combination of means of three independent experiments with six replicates (plantlets) per strain or mutant in each experiment. Note that two to four leaves were imprinted per plantlet. Although there can be significant variability between means of ELA between plantlets, all data are used for statistical analysis. 
2. For the determination of leaf attachment by leaf washing and leaf homogenization, data are from 20 leaves and combined from two separate experiments of five plantlets each (two leaves sampled per inoculated sugarcane plantlet and five plantlets used at each sampling time). Individual population data (CFU/ml) are transformed using the $\log 10$ function $\left(y=\log _{10}[(\mathrm{CFU} / \mathrm{ml})\right.$ $+1]$ ) before calculation of population means. When appropriate (few nil data), individual log transformed data can be used for mean comparison by variance analysis.

3. Data obtained by leaf imprinting (semi-quantitative method) and leaf washing (quantitative method) are correlated and yield similar information as they are both linked to bacterial populations present on the leaf surface. In contrast, data obtained by leaf homogenization are linked to bacteria that cannot be easily detached from the leaf surface and that are located in protected leaf areas or inside the leaf. Leaf imprinting is recommended for rapid and easy screening of bacterial strains for leaf attachment capacity. Leaf washing/homogenization is recommended to obtain more precise and quantitative data, and additional information regarding location of bacteria on or in the leaf.

\section{$\underline{\text { Notes }}$}

1. Bacterial suspension preparation, plantlet sugarcane immersion, and foliar imprints are performed under a laminar flow cabinet (sterile conditions).

2. The bacterial suspension used to inoculate sugarcane plantlets is prepared freshly (just before the inoculation procedure). The bacterial suspension is prepared with only a few single colonies to obtain the desired bacterial concentration. The number of colonies used will depend on the size of the colonies. The bacterial strains stored in the freezer at minus $80^{\circ} \mathrm{C}$ are each issued from a single colony.

3. Choose carefully the sugarcane leaves for imprinting or washing; we choose only green and non-withered leaves.

4. The area of confluent growth was estimated visually using a template with $10 \%$ leaf area increments.

5. Sugarcane cultivar CP68-2016 was used herein but other cultivars susceptible to sugarcane leaf scald can also be tested.

Non-specific adhering was not observed with the bacterial strains used herein. However, it can be a good idea to identify and include a bacterial species not adapted to sugarcane as a negative control.

\section{$\underline{\text { Recipes }}$}

1. Wilbrink medium (WM) (1 L)

$10 \mathrm{~g}$ sucrose

$5 \mathrm{~g}$ peptone 
$0.50 \mathrm{~g} \mathrm{~K}_{2} \mathrm{HPO}_{4} \cdot 3 \mathrm{H}_{2} \mathrm{O}$

$0.25 \mathrm{~g} \mathrm{MgSO}_{4} \cdot 7 \mathrm{H}_{2} \mathrm{O}$

$0.05 \mathrm{~g} \mathrm{Na}_{2} \mathrm{SO}_{3}$

$15 \mathrm{~g}$ agar

Add distilled water to make up $1 \mathrm{~L}$

Adjust $\mathrm{pH}$ to $6.8-7.0$

Autoclave $20 \mathrm{~min}$ at $121^{\circ} \mathrm{C}$

2. Wilbrink Selective Davis (WSD) medium (1L)

Same composition as WM medium but supplemented with:

$5 \mathrm{~g} \mathrm{KBr}$ and $0.004 \mathrm{~g}$ Benomyl (fungicide) before heat sterilization

After autoclaving, add:

$0.1 \mathrm{~g}$ cycloheximide dissolved in $500 \mu \mathrm{l}$ ethanol

$0.025 \mathrm{~g}$ cephalexin dissolved in $500 \mu \mathrm{l}$ sterile distilled water

$0.03 \mathrm{~g}$ novobiocin dissolved in $500 \mu \mathrm{l}$ ethanol

$0.05 \mathrm{~g}$ kasugamycin dissolved in $500 \mu \mathrm{l}$ sterile distilled water

3. Macronutrients $(1 \mathrm{~L})$

$10 \mathrm{~g} \mathrm{NH}_{4} \mathrm{NO}_{3}$

$10 \mathrm{~g} \mathrm{KNO}_{3}$

$5 \mathrm{~g} \mathrm{Ca}\left(\mathrm{NO}_{3}\right)_{2} \cdot 4 \mathrm{H}_{2} \mathrm{O}$

$715 \mathrm{mg} \mathrm{MgSO} \cdot 7 \mathrm{H}_{2} \mathrm{O}$

$3 \mathrm{~g} \mathrm{KH}_{2} \mathrm{PO}_{4}$

$650 \mathrm{mg} \mathrm{KCl}$

Add distilled water to make up to $1 \mathrm{~L}$

4. Micronutrients $(100 \mathrm{ml})$

$160 \mathrm{mg} \mathrm{H}_{3} \mathrm{BO}_{3}$

$1,400 \mathrm{mg} \mathrm{MnSO} \mathrm{H}_{4} \cdot \mathrm{H}_{2} \mathrm{O}$

$380 \mathrm{mg} \mathrm{ZnSO} \cdot 7 \mathrm{H}_{2} \mathrm{O}$

$75 \mathrm{mg} \mathrm{KI}$

$10 \mathrm{mg}\left(\mathrm{NH}_{4}\right)_{6} \mathrm{Mo}_{7} \mathrm{O}_{24} \cdot 4 \mathrm{H}_{2} \mathrm{O}$

$35 \mathrm{mg} \mathrm{Cu}\left(\mathrm{NO}_{3}\right)_{2} \cdot 3 \mathrm{H}_{2} \mathrm{O}$

Add distilled water to make up to $100 \mathrm{ml}$

Solution to be stored at $-20^{\circ} \mathrm{C}$ in $1.5 \mathrm{ml}$ micro-centrifuge tubes

5. Ferric EDTA

$2.78 \mathrm{~g} \mathrm{FeSO}_{4} \cdot 7 \mathrm{H}_{2} \mathrm{O}$

$3.73 \mathrm{~g} \mathrm{Na} 2 \mathrm{EDTA} \cdot 2 \mathrm{H}_{2} \mathrm{O}$

$500 \mathrm{ml}$ distilled water

Dissolve $\mathrm{Na}_{2}$ EDTA and $\mathrm{FeSO}_{4}$ separately and add $\mathrm{FeSO}_{4}$ to $\mathrm{Na}_{2}$ EDTA by mild heating of the solution

6. Fuji vitamins 
$50 \mathrm{mg}$ nicotinic acid (in boiling water)

$10 \mathrm{mg}$ pyridoxol hydrochlorid

10 g myo-inositol

$10 \mathrm{mg}$ thiamine dichloride (to be added last)

Add distilled water to make up to100 $\mathrm{ml}$

Solution to be stored at $-20^{\circ} \mathrm{C}$ in $1.5 \mathrm{ml}$ micro-centrifuge tubes

7. Nutritive medium for growth of sugarcane plantlets (1 L) (Adapted from Chatenet et al., 2001)

$100 \mathrm{ml}$ macronutrients

$1 \mathrm{ml}$ micronutrients

$5 \mathrm{ml}$ Ferric EDTA

$2 \mathrm{ml}$ Fuji vitamins

$8 \mathrm{~g}$ agar or $4 \mathrm{~g}$ Phytagel

$40 \mathrm{~g}$ sucrose

$890 \mathrm{ml}$ distilled water

pH 5.8

Autoclave for 20 min at $121{ }^{\circ} \mathrm{C}$

\section{Acknowledgments}

We thank Marie-Josée Darroussat for excellent technical assistance. Imène Mensi was supported by a PhD fellowship from Cirad. The work is supported by the USDA National Institute of Food and Agriculture [project Hatch/Rott FLA-BGL-005404]. This protocol was adapted from work published by Fleites et al. (2013) and Mensi et al. (2016).

\section{References}

1. Birch, R. G. (2001). Xanthomonas albilineans and the antipathogenesis approach to disease control. Mol Plant Pathol 2(1): 1-11.

2. Chatenet, M., Delage, C., Ripolles, M., Irey, M., Lockhart, B. E. L. and Rott, P. (2001). Detection of Sugarcane yellow leaf virus in quarantine and production of virus-free sugarcane by apical meristem culture. Plant Dis 85(11): 1177-1180.

3. Fleites, L. A., Mensi, I., Gargani, D., Zhang, S., Rott, P. and Gabriel, D. W. (2013). Xanthomonas albilineans OmpA1 appears to be functionally modular and both the OMC and C-like domains are necessary for leaf scald disease of sugarcane. Mol Plant Microbe Interact 26(10): 12001210.

4. Hirano, S. S. and Upper, C. D. (2000). Bacteria in the leaf ecosystem with emphasis on Pseudomonas syringae-a pathogen, ice nucleus, and epiphyte. Microbiol Mol Biol Rev 64(3): 624-653. 
5. Kumar, N. and Reddy, M. P. (2011). In vitro plant propagation: A review. J Forest Sci 27(2): 6172.

6. Mensi, I., Daugrois, J. H., Pieretti, I., Gargani, D., Fleites, L. A., Noell, J., Bonnot, F., Gabriel, D. W. and Rott, P. (2016). Surface polysaccharides and quorum sensing are involved in the attachment and survival of Xanthomonas albilineans on sugarcane leaves. Mol Plant Pathol 17(2): 236-246.

7. Rott, P., Fleites, L., Marlow, G., Royer, M. and Gabriel, D. W. (2011). Identification of new candidate pathogenicity factors in the xylem-invading pathogen Xanthomonas albilineans by transposon mutagenesis. Mol Plant Microbe Interact 24(5): 594-605.

8. Yadav, R. K. P., Kakamanoli, K. and Vokou, D. (2010). Estimating bacterial population on the phyllosphere by serial dilution plating and leaf imprint methods. Ecoprint 17: 47-52. 